\title{
The effectiveness of the determinants of banking credit growth
}

\author{
Suarni Norawati ${ }^{\mathrm{a}}$, Zulher $^{\mathrm{a}}$, Kasmawati ${ }^{\mathrm{a}}$ and Cicih Ratnasih ${ }^{\mathrm{b} *}$
}

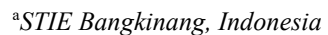

${ }^{b}$ Universitas Borobudur, Indonesia

\section{H R O N I C L E}

\begin{tabular}{l}
\hline Article history: \\
Received September 26, 2021 \\
Received in revised format \\
October 292021 \\
Accepted December 22021 \\
Available online \\
December 22021 \\
\hline Keywords: \\
Third Party Funds \\
Operational Costs \\
Credit Growth
\end{tabular}

\section{A B S T R A C T}

This study discusses the variables that can determine the growth of bank credit in Indonesia. The selected independent variables are the control of third-party funds and operating costs on credit growth. The analytical method used is multiple regression with Probit analysis to see the lag-1 and lag-2 data categories. The results obtained that the Control of Third Parties Funds and Operational Costs on Credit Growth obtained significant results according to the simultaneous hypothesis testing. It means that the third-party funds and the operating costs affect credit growth. Meanwhile, the third-party funds partially influence the dependent variable, namely credit growth. Finally, the operational costs partially influence the dependent variable, namely credit growth.

\section{Introduction}

Banking is one of the financial institutions which plays a major effect on the economy in society in a country, especially in the field of economic financing. Banks as financial institutions are a place for various parties such as private companies, individuals, and government agencies to store their funds. Banks function to collect funds from the public and channel them back through credit. According to Baoko et al. (2017), the strength of the banking system is an essential requirement to ensure stability and economic growth. Stability and economic growth can be achieved since the bank is an appropriate intermediary for two parties, namely those who have excess funds and, on the other hand, those who need funds. For those who have excess funds, banks can be used to store funds and increase the number of their funds. Meanwhile, for those who need funds, banks can be used to borrow funds for their capital and consumption needs. With the role of banks in facilitating the circulation of money in the economy, there are various threats and problems. The main problems that are most often faced by every bank and other company engaged in any business are always inseparable from the need for funds (capital) to finance their business, and the need for these funds is needed either for investment capital or labor capital. Therefore, we need bank security where the bank is required to manage its activities and overcome the problems that always arise, especially in the field of controlling their assets so that the bank's operational implementation reaches its goals properly.

Companies with a good internal control system can separate functional responsibilities, have good authorization systems and recording procedures, and have adequate resources. The internal control system is not a system that is intended to avoid all possible errors or irregularities that occur. A good internal control system is where a company can suppress errors and irregularities that may occur. A good control function based on good management and financial system will also make activities within the company smooth and controlled (KIM, 2016).

* Corresponding author.

E-mail address: cicih ratnasih@,borobudur.ac.id (C. Ratnasih) 
Each company certainly has its own control system in terms of regulating all activities carried out. It is intended to achieve the goals set by the company. The achievement of these goals is carried out through many things, one of which is establishing several internal controls or supervisions. Good internal control avoids fraud, such as making changes to reports or calculations. Appropriate recording procedures so that sophisticated controls can be carried out or even the best system is prepared may not necessarily be able to avoid mistakes if there is a conspiracy from employees to commit fraud which can render the control useless. Optimal profit is the goal of the company in general. The fundamental objective of the banking business is to obtain optimal profits by providing financial services to the public (Dao \& Ankenbrand, 2015). Large assets and high profits are part of the success achieved by companies in general which are often referred to as part of financial performance. A bank that always maintains good performance, especially a high level of profitability, can distribute dividends properly, and its business prospects can always develop and meet the provisions of prudential banking regulation well. Then there is a possibility of the value of the bank's shares concerned in the secondary market and the number of thirdparty funds. Third-party funds collected will increase (Daghestani et al., 2014). The increase in shares and the amount of third-party funds is one indicator of increasing public trust in banks. Third-party funds are the total funds raised by the bank and successfully collected from the public. This Total Third Party Fund shows the bank's success in raising funds in the form of deposits, demand deposits, and deposits, which are then channeled back to the public in the form of credit. Based on the importance of funds sourced from the public, in principle, these funds must be managed by the bank as well as possible and based on the precautionary principle so that the funds are safe and there are no deviations that will lead to the realization of risks in the banking world which will have an impact on the loss of public trust, against the bank itself. So, Banks should have a good Internal Control System to guarantee and protect public trust itself. The daily operations of the bank required fees to process transactions (operational costs). These costs are directly related to the period they are incurred; therefore, they must be recorded and recognized as current period costs. The costs incurred by this bank have no benefits for the future. Operational costs or operating costs are not directly related to the company's products but are related to the company's daily operational activities, and this type of cost is the largest portion of the overall bank costs. This type of operational costs relates to employees such as allowances, third party service fees, office operational costs that are not employee costs or depreciation, and other types of costs incurred or related to the financial reporting period.

Without costs, business activities cannot be carried out. If the business is not carried out, the bank will not receive income and profit. Profit itself is obtained from the income received minus the costs incurred. In order to obtain high profits, the costs incurred must be managed as efficiently as possible because if the costs incurred are greater than the income, the bank will suffer losses. Cost efficiency is a complex issue where every bank always tries to provide the best service to customers, but at the same time, banks must also try to manage their costs well. The problems in this research are:

1) How much influence does the variable controlling third party funds and operating cost variables have simultaneously on the growth of bank credit in Indonesia?

2) How much influence does the third-party fund variable have on the banking credit growth in Indonesia?

3) How big is the influence of operational costs on credit growth in Indonesia?

\section{Theory}

In carrying out their daily business activities, banks must have funds to provide credit to the public. Funds can be obtained from bank owners (shareholders), the government, the central bank, parties abroad, and domestic communities. Public funds are collected by banks using deposit product instruments consisting of Current Accounts, Time Deposits, and Savings. Identical banks provide the three deposit products with the three motives for controlling money (Myers \& Majluf, 1984). Keynes, with the Liquidity of Preference Theory, divides three motives for holding money, namely: Transaction motive, which is the motive to pay for a transaction trade Precautionary motive, which is the motive to be on guard if there is a sudden need Speculative motive, namely the motive to speculate to obtain high profits. The funds raised by the banks mentioned above must be redistributed to the public in credit. It is done because the bank's function is as an intermediary between parties who have excess funds and those who lack funds, and the bank's profits are obtained from the difference between the selling price and the purchase price of the funds after deducting operational costs (Mushinski, 1999). Thus, banks must be able to place these funds in the most profitable form of placement. In general, the most profitable placement of funds is in the form of credit; however, the risks faced by banks in placing these funds are also large (Ullah et al., 2012). Therefore, banks must be careful in placing funds in the form of credit. Credit is the provision of money or equivalent claims based on an agreement or loan agreement between a bank and another party that requires the borrower to repay his debt after a certain period with interest (Mushinski, 1999). In granting credit to customers, policies are needed to create a good credit management system. The policy of providing credit is one of the policies that banks often carry out to increase the volume of lending, which will increase profits (Stiglitz \& Weiss, 1981). The bank is an intermediary institution between surplus units and deficit units. Furthermore, channeling credit is a moral obligation of banking, can be stated in such a way because the main source of bank funds comes from the community, so it is only natural that banks must redistribute them to the public in the form of credit (Botello Peñaloza, 2015). In channeling credit, banks are required to continue to grow healthily every year. Uncontrolled credit growth aimed at the wrong borrowers can lead to non-performing loans in the future (Baoko et al., 2017). 
The high credit growth can be triggered by liberalization in the financial sector, which is designed to increase the depth of the financial sector. Another factor contributing to the increase in credit was the presence of capital inflows, where capital inflows would increase the supply of funds by banks, which increased credit growth. In contrast, credit growth can also occur due to an excessive response from financial actors due to changes in risk from time to time (Baoko et al., 2017). To get credit customers is increasing, causing banks to lower lending standards in getting new customers, and economic growth is increasing. Considering that non-performing loans that have occurred in previous years have been completed, banks are becoming more daring in taking risks. Whatever the reason, very fast credit growth will impact growing losses on credit and reduce profits for banks which can then become a problem for banks (Duican \& Pop, 2015). The point of view that rapid credit growth causes credit non-performing loans cannot be ignored. If rapid credit growth occurs, the banks want to channel credit by lowering their standards and increasing non-performing loans. However, if high credit growth occurs because of a change in the perspective of businesspeople with profitable businesses where they prefer to borrow from banks compared to obtaining additional funds from the capital market, growth in non-performing loans should not occur. The various types of business activities result in various needs for the type of credit needed. Banks' provision of credit facilities is grouped into types, each of which is viewed from various aspects. This type of division is intended to achieve certain goals or objectives, considering that each type of business has certain characteristics. Third-party funds are very important for banks in raising funds because, for their business interests, the bank collects funds from the bank itself (the first party), funds from other parties (second party funds), and funds from the public or third parties in the form of savings, deposits and other sources of funds. The greater income generated by the bank, the bigger the opportunity for the bank to generate its profits. The bank will be more interested in increasing the amount of distribution of funds to the public. Meanwhile, according to Hasan et al. (2017), third party funds, usually known as public funds, are funds collected by banks that come from the community in a broad sense, including individual communities, as well as business entities.

Cost is the main physical element that must be sacrificed for the sake of the interests and smooth running of the company to generate profit, which is the company's main goal. Therefore, its implementation requires very serious attention in addition to cost is also an element of a very large reduction concerning the search for net income. Cost also plays an important role in calculating the cost of goods, planning, and control. According to Brigham and Erhardt (2005), cost is the sacrifice of economic resources, measured in units of money, that has occurred or is likely to earn a profit. The sacrifice of economic resources can be seen from the four elements contained therein, namely, the cost is a sacrifice of economic resources in the form of cash or its equivalent, which can be measured in monetary units of money, is something that happens or has the potential to happen. The sacrifice is made to achieve certain goals in the future, to earn income.

\section{Method}

The quantitative method is research that uses data analysis in the form of numeric/numbers. This approach describes data through numbers. The purpose of quantitative research is to develop and to use mathematical models, theories, and hypothetical data related to phenomena. In the context of this research, the researcher did not intervene or manipulate the formation of research data, and the essence of this research was to see the relationship between the variables, namely thirdparty Funds (X1), Operational Costs (X2), which will affect the variable Credit Growth (Y), to find out how much influence either partially or simultaneously. The approach used in this research is quantitative. The type of data in this study is secondary data. Models and analysis techniques using multiple linear regression. Secondary data is data that is already available and used for another research. The method of data collection in this research is documentation, namely collecting data by using documents related to this research. The documentation method is based on observations from researchers both directly and indirectly on the object under study using research guidelines in the form of data collected, namely Third-Party Funds (X1), Operational Costs (X2), Credit Growth (Y). The analysis technique in this study was carried out using multiple linear regression analysis. Before testing with multiple linear regression, the classical assumption test was first performed, which consisted of normality test, multicollinearity test, heteroscedasticity test, and autocorrelation test. Multiple regression analysis aims to see the effect between the independent variable and the dependent variable. This test was carried out using the Eviews-9 program for the windows operating system. After the regression model is free from deviations from classical assumptions, the next step is to conduct statistical tests consisting of t-test and f-test. Before testing the hypothesis with multiple linear regression analysis, it is necessary to test the classical assumptions first. The classical assumption test in this study is used to determine the relationship between research variables in the regression model.

Multiple regression analysis is a statistical method used to determine the possible form of relationship between variables. The main purpose of using this method is to predict and estimate the value of a model as follows:

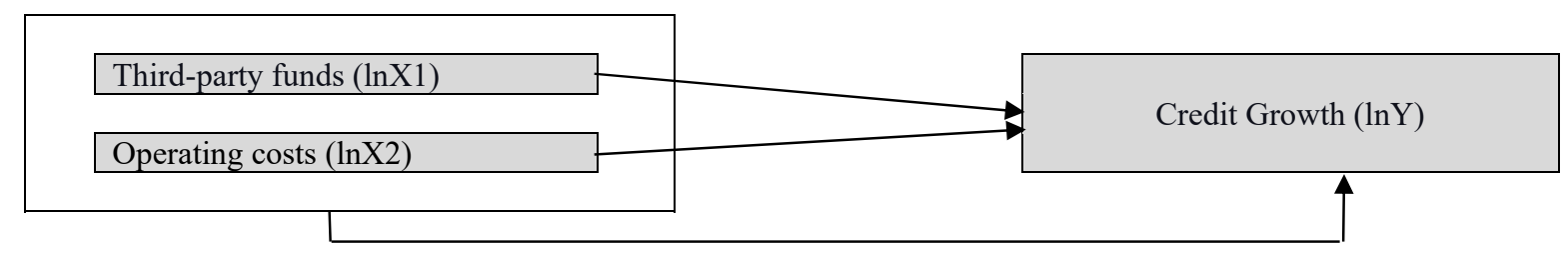

Fig. 1. The proposed study 
Information:

$$
\begin{aligned}
& \ln \mathrm{Y}=\mathrm{a}+\mathrm{b}_{1} \ln \mathrm{X}_{1}+\mathrm{b}_{2} \ln \mathrm{X}_{2}+\mathrm{u} \\
& \ln \mathrm{Y}=\text { Credit Growth } \\
& \mathrm{a}=\text { constant. } \\
& \beta 1=\text { first regression coefficient } \\
& \beta 2=\text { second regression coefficient } \\
& \ln \mathrm{X} 1=\text { Third Party-Funds } \\
& \ln \mathrm{X} 2=\text { Operating Costs }
\end{aligned}
$$

\section{Research results and discuss}

Hypothesis Testing is a statistical method aimed at testing the effect of independent variables on the dependent variable by predicting and estimating how the state of the rise and fall of the value of a variable under study. Multiple regression test results can be seen in Table 1 below:

\section{Table 1}

The results of the regression analysis

\begin{tabular}{llll}
\hline Variable & Coefficient & Std. Error & t-Statistic \\
\hline C & 2167.724 & 964.9642 & 6.488013 \\
lnDPK & 2.573951 & 0.064010 & 2.710032 \\
lnBOPR & -1.412062 & 0.002880 & -3.390331 \\
\hline R-squared & 0.685402 & Mean dependent var & 30031.10 \\
Adjusted R-squared & 0.459551 & S.D. dependent var & 12478.03 \\
S.E. of regression & 6.27098 & Akaike info criterion & 0.0004 \\
Sum squared resid & $2.73 \mathrm{E}+03$ & Schwarz criterion & 0.0062 \\
Log likelihood & -387.5643 & Hannan-Quinn criter. & 10.61997 \\
F-statistic & 9.295159 & Durbin-Watson stat & 5.386033 \\
Prob(F-statistic) & 0.003713 & & 1.989827 \\
\hline Source: Data prat & & \\
\end{tabular}

Source: Data processed E-views 9

Based on the multiple linear regression calculations shown in Table 1, the regression line equation is as follows:

$$
\mathrm{Y}=2167.724+2.573956-1.412062+\mathrm{ei}
$$

$$
(2.710032)(-3.390331)
$$

The multiple linear regression equation can be explained as follows:

1. Third Party Funds Variable (X1) obtained a coefficient value of 2.573951, which indicates that if the Third-Party Funds variable increases by 1 unit, then Credit Growth will increase by 2.573951 units with the assumption that other independent variables are in constant condition.

2. Variable Operating Costs (X2) obtained a coefficient value of -1.412062 , which indicates that if the Operating Cost variable increases by 1 unit, then Credit Growth will decrease by -1.412062 with the assumption that other independent variables are in constant condition.

3. The constant of 2167,724 explains that if all independent variables are constant or equal to zero, the amount of Credit Growth is 2167,724 units.

The F test is used to test the regression model for the effect of all independent variables, namely X1 and X2, simultaneously on the dependent variable. The criteria in this test are as follows:

1. If the significance is greater than $5 \%$, it can be concluded that Ho is accepted; otherwise, Ha is rejected.

2. If the significance is less than $5 \%$, it can be concluded that Ho is rejected; otherwise, Ha is accepted.

Based on table 1, it can be seen that there is a simultaneous influence of Third- Party Funds and Operational Costs on Credit Growth. From the table, the F-statistic is 9.295159, and the significance is 0.003713 . The Prob. value (F-statistic) is less than 0.05 , indicating that Third Party Funds and Operational Costs simultaneously have a positive and significant effect on Credit Growth, so the first hypothesis is accepted.

The t-test aims to determine the effect and significance of each independent variable on the dependent variable. The criteria in this test are as follows:

Ho: if the p-value $>0.05$, then Ho is accepted, and Ha is rejected.

$\mathrm{Ha}$ : if $\mathrm{p}$-value $<0.05$, then Ho is rejected, and Ha is accepted. 
The results of the t-test of the independent variable on the dependent variable are as follows:

1. The Third-Party Fund Control Variable has a positive and significant effect on Credit Growth. Based on table 1, the multiple linear regression test results obtained a regression coefficient of 2.573956. Third-party funds are variable with a t-statistic of 2.710032 , probability of 0.0004 . The probability value less than 0.05 indicates that the Third-Party Fund variable has a positive and significant effect on Credit Growth.

2. Variable Operating Costs have a negative and significant effect on Credit Growth. Based on table 1, the multiple linear regression test results obtained a regression coefficient value of -1.412062 . Variable Operational Costs has a t-Statistic of -3.390331 with a probability of 0.0062 . The probability value less than 0.05 indicates that the variable operating costs have a negative and significant effect on credit growth.

3. It is more effective to control third party funds than operational costs. seen from the beta coefficient that has been obtained.

The coefficient of determination (Adjusted $\mathrm{R}^{2}$ ) aims to measure how far the model's ability to explain the dependent variables. The value of the coefficient of determination is between zero and one. A smaller Adjusted $\mathrm{R}^{2}$ value means that the abilities of the independent variables in explaining the dependent variables are very limited.

Based on Table 1, the Adjusted $\mathrm{R}^{2}$ value is 0.459551 . It shows that Third Party Funds and Operational Costs influence credit Growth by $68.5 \%$, other factors outside this research influence the remaining $31.5 \%$. This discussion describes the analysis of each variable using the multiple regression analysis methods, which can be explained as follows:

Whereas the analysis of the variables of Third-Party Funds and Operational Costs on Credit Growth, the results follow the hypothesis test that simultaneously has a significant positive effect. It means that third-party funds and operating costs simultaneously significantly affect credit growth, with a contribution value of $68.5 \%$. In the research of Abuhommous (2017), Zulher and Ratnasih (2021) that credit growth is influenced by the cost factors incurred. While for Third-Party Funds on Credit Growth, it partially affects the beta coefficient of 2.573956 with a significant value of 0.0004 because the significant value is less than 0.05 , meaning that third-party funds partially influence the dependent variable, namely credit growth. The variable operating costs on credit growth partially affect the beta coefficient of -1.412062 with a significant value of 0.0062 ; because the significant value is less than 0.05 , the hypothesis is accepted, meaning that operational costs partially influence the dependent variable, namely credit growth.

\section{Conclusion}

Based on the results of the discussion of data analysis through proving the hypothesis of the problems raised regarding the Analysis of Third-Party Fund Control Systems and Operational Costs on Banking Credit Growth in Indonesia, conclusions can be drawn from this study as follows:

1. Third-party control and operational costs affect credit growth in Indonesia, and it can be seen from the results of the F test, which simultaneously have an effect that these two variables need special attention.

2. Control of third-party funds is significant for credit growth, meaning that this variable needs special attention from bank credit managers for the continuation of lending going forward.

3. Operational costs as the second variable get a significant negative position on credit growth in Indonesia, which can be interpreted if operational costs increase. Credit growth in Indonesia will decrease, therefore in this case, Indonesia is still sensitive to costs.

\section{References}

Afrifa, G. A., \& Gyapong, E. (2017). Net trade credit: what are the determinants? International Journal of Managerial Finance, 13(3), 246-266. doi: doi:10.1108/IJMF-12-2015-0222.

Abuhommous, A. A. A. (2017). The impact of offering trade credit on firms' profitability. Journal of Corporate Accounting \& Finance, 28(6), 29-40. DOI: 10.1002/jcaf.22298.

Akoijam, S. L. (2013). Rural credit: a source of sustainable livelihood of rural India. International Journal of Social Economics, 40(1), 83-97.

Baoko, G., Acheampong, I. A., \& Ibrahim, M. (2017). Determinants of bank credit in Ghana: a bounds-testing cointegration approach. African Review of Economics and Finance, 9(1), 33-61.

Botello Peñaloza, H. A. (2015). Determinants of access to credit for SMEs: evidence at the level of the firm in Latin America. Apuntes del cenes, 34(60), 247-276.

Brigham, E.F., \& Erhadt, M.C. (2005). Financial Management Theory and Practice. $11^{\text {th }}$ ed., Ohio: South Western.

Duican, E. R., \& Pop, A. (2015). The implications of credit activity on economic growth in Romania. Procedia Economics and Finance, 30, 195-201. doi:10.1016/S2212-5671(15)01286-1.

Dao, T.B., \& Ankenbrand, T. (2015). Capital Adequacy and Banking Risk - An Empirical Study on Vietnamese Banks. Ideas, Hanoi: Seminar on Hanoi University and AVACO AG and University of Zurich. Available from: 
https://papers.ssrn.com/sol3/Delivery.cfm/ SSRN_ID2530371_code434862.pdf?abstractid=2524233\&mirid=1. [Last diakses on 2015 Agu 25].

Daghestani, A., Mrad, S., \& Payne, B.C. (2014). A Financial Profile of those Firms that Maintained or Increased Market Value During a Period of Economic Recession and Financial Market Turmoil. Working Paper, Barry University.

Fairchild, R. (2010). Dividend Policy, Signalling and Free Cash Flow: an Integrated Approach. Managerial Finance, 36 (5), 394- 413.

Hasan, I., Jackowicz, K., Kowalewski, O., \& Kozłowski, Ł. (2017). Do local banking market structures matter for SME financing and performance? New evidence from an emerging economy. Journal of Banking \& Finance, 79, $142-158$. doi: https://doi.org/10.1016/j.jbankfin.2017.03.009

KIM, W. S. (2016). Determinants of corporate trade credit: An empirical study on Korean firms. International Journal of Economics and Financial Issues, 6(2), 414-419.

Myers, S.C., \& Majluf, N.S. (1984). Corporate financing and investment decisions when firms have information, that investors do not have. Journal of Financial Economics, 12, 187-221.

Mushinski, D. (1999). An analysis of offer functions of banks and credit unions in Guatemala. Journal of Development Studies, 26, 88-112. https://doi.org/10.1080/00220389908422622

Nguyen, M., Arovas, G., Broach, D., Cateriano, H., \& Righi, P. (2004). The Development Impact of Small and Medium Enterprises: Lessons Learnt from SEAF Investments (p. 33). Washington DC: Small Enterprise Assistance Funds.

Shirota, T. (2013). What is the Major Determinant of Credit Flows through Cross-border Banking? : Bank of Japan.

Stiglitz, J.E., \& Weiss, A. (1981). Credit rationing in markets with imperfect information. The American Economic Review, 71(3), 393-410.

Sawicki, J. (2008). Corporate Governance and Dividend Policy in Souteast Asia: Pre- and Post-Crisis. The European Journal of Finance, 15(2), 211-230.

Ullah, H., Asma Fida, \& Khan, S. (2012). The Impact of Ownership Structure on Dividend Policy Evidence from Emerging Markets KSE-100 Index Pakistan. International Journal of Business and Social Science, 3(9), 298-307.

Zulher, Z., \& Ratnasih, C. (2021). Financial development and poverty reduction in developing countries. Accounting, 7(3), 667-674.

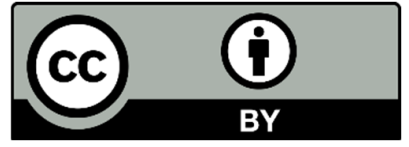

(C) 2022 by the authors; licensee Growing Science, Canada. This is an open access article distributed under the terms and conditions of the Creative Commons Attribution (CC-BY) license (http://creativecommons.org/licenses/by/4.0/). 